\title{
A Review of Feral Cat Eradication on Islands
}

\author{
MANUEL NOGALES,${ }^{*} \dagger \dagger$ AURELIO MARTÍN,${ }^{*}$ BERNIE R. TERSHY, $\uparrow$ C. JOSH DONLAN, $† \ddagger$ \\ DICK VEITCH,, NÉSTOR PUERTA, ${ }^{*}$ BILL WOOD $\uparrow \uparrow$ AND JESÚS ALONSO* \\ * Departamento de Biología Animal (Zoología), Universidad de La Laguna, 38206 Tenerife, Canary Islands, Spain \\ †Island Conservation and Ecology Group, Long Marine Laboratory, University of California, Santa Cruz, CA 95060, U.S.A. \\ $\ddagger$ Department of Ecology and Evolutionary Biology, Cornell University, Ithaca, NY 14853, U.S.A. \\ $\S 48$ Manse Road, Papakura, New Zealand
}

\begin{abstract}
Feral cats are directly responsible for a large percentage of global extinctions, particularly on islands. We reviewed feral cat eradication programs with the intent of providing information for future island conservation actions. Most insular cat introductions date from the nineteenth and twentieth centuries, whereas successful eradication programs have been carried out in the last 30 years, most in the last decade. Globally, feral cats have been removed from at least 48 islands: 16 in Baja California (Mexico), 10 in New Zealand, 5 in Australia, 4 in the Pacific Ocean, 4 in Seychelles, 3 in the sub-Antarctic, 3 in Macaronesia (Atlantic Ocean), 2 in Mauritius, and 1 in the Caribbean. The majority of these islands $(75 \% ; \mathrm{n}=36)$ are small $(\leq 5$ $\mathrm{km}^{2}$ ). The largest successful eradication campaign took place on Marion Island (290 $\left.\mathrm{km}^{2}\right)$, but cats bave been successfully removed from only 10 islands (21\%) of $\geq 10 \mathrm{~km}^{2}$. On Cousine Island (Seychelles) cat density reached $243 \mathrm{cats} / \mathrm{km}^{2}$, but on most islands densities did not exceed $79.2 \mathrm{cats} / \mathrm{km}^{2}$ ( $\mathrm{n}=22 ; 81 \%$ ). The most common methods in successful eradication programs were trapping and hunting (often with dogs; $91 \%$ from a total of 43 islands). Frequently, these methods were used together. Other methods included poisoning (1080; monofluoracetate in fish baits; $\mathrm{n}=13 ; 31 \%)$, secondary poisoning from poisoned rats $(\mathrm{n}=4 ; 10 \%)$, and introduction of viral disease (feline panleucopaenia; $\mathrm{n}=2 ; 5 \%$ ). Impacts from cat predation and, more recently, the benefits of cat eradications have been increasingly documented. These impacts and benefits, combined with the continued success of eradication campaigns on larger islands, show the value and role of feral cat eradications in biodiversity conservation. However, new and more efficient techniques used in combination with current techniques will likely be needed for success on larger islands.
\end{abstract}

Key Words: eradication, Felis catus, feral cat, islands, predation effect

Revisión de la Erradicación de Gatos Asilvestrados en Islas

Resumen: Los gatos asilvestrados han sido responsables directos de un gran número de extinciones, particularmente en islas. En este estudio, se revisan los programas de erradicación de este felino con el fin de ofrecer información de utilidad en futuras acciones de conservación en islas. La mayor parte de las introducciones datan de los siglos diecinueve y veinte, mientras que las erradicaciones han sido realizadas básicamente durante los últimos 30 años, y sobre todo en la última década. Los gatos asilvestrados han sido erradicados de al menos 48 islas: 16 de ellas en Baja California (México), 10 en Nueva Zelanda, 5 en Australia, 4 en el Océano Pacífico, 4 en Seychelles, 3 en la Región Subantártica, 3 en Macaronesia (Océano Atlántico), 2 en Mauricio, y una en el Caribe. La mayoría de éstas $(75 \% ; \mathrm{n}=36)$ son de reducidas dimensiones $\left(\leq 5 \mathrm{~km}^{2}\right)$, mientras que la más extensa es Marion Island $\left(290 \mathrm{~km}^{2}\right)$. En tan sólo 10 islas $(21 \%) \geq 10 \mathrm{~km}^{2}$ se ba podido erradicar este depredador. En Cousine Island (Seychelles) la densidad de gatos alcanzó 243 individuos $/ \mathrm{km}^{2}$; sin embargo, en la mayoría de las islas, las densidades no excedieron los 79,2 individuos $/ \mathrm{km}^{2}(\mathrm{n}=22 ; 81 \%)$. Los métodos más comúnmente empleados fueron el trampeo y la caza, a menudo con perros (91\% de un total de 43 islas). Con frecuencia dichas prácticas fueron empleadas conjuntamente. Otros métodos incluyeron venenos (1080, monofluoracetato

††emailmnogales@ull.es

Paper submitted October 16, 2002; revised manuscript accepted June 5, 2003.

310

Conservation Biology, Pages 310-319

Volume 18, No. 2, April 2004 
de sodio en cebos de pescado: $\mathrm{n}=13 ; 31 \%)$, envenenamiento secundario con ratas envenenadas $(\mathrm{n}=4 ;$ $10 \%)$ y el virus de la leucemia felina $(\mathrm{n}=2 ; 5 \%)$. La información sobre el efecto negativo de los gatos en islas $y$, más recientemente, el beneficio de su erradicación, se ba ido dando a conocer paulatinamente, poniendo de manifiesto su importancia en la conservación de la biodiversidad insular. No obstante, la combinación de técnicas nuevas y más eficientes junto con las habituales, será necesaria para el éxito de la erradicación de los gatos en islas de grandes dimensiones.

Palabras Clave: efecto de depredación, erradicación, Felis catus, gato asilvestrado, islas

\section{Introduction}

Since domestication from the African wildcat (Felys silvestris libyca) some 4000 years ago (Randi \& Ragni 1991; Serpell 2000), cats (Felis catus) have traveled widely as human commensals, often establishing feral populations (Todd 1977). Effects of predation on native species by feral cat populations are widespread and significant, particularly on islands (Whittaker 1998). In these insular environments, feral cats are directly responsible for a number of extinctions and extirpations worldwide and across multiple taxa (Iverson 1978; Moors 1985; Kirkpatrick \& Rauzon 1986; Cruz \& Cruz 1987; Towns et al. 1990; Donlan et al. 2000; Veitch 2001). Due to high levels of species, behavioral, and genetic diversity on islands, these effects contribute significantly to the reduction of biological diversity (Stone et al. 1994; Groombridge \& Jenkins 2000; Atkinson 2001; McNeely et al. 2001). These negative effects and their wide distribution have resulted in the cat being included in the list of the 100 worst invasive species (Lowe et al. 2001).

In response to the problem of feral cats, techniques have been developed to remove populations from islands (Veitch 1985; Wood et al. 2002). Over the past two decades, these conservation techniques have prevented the extinction of insular species and restored many island ecosystems (Forsell 1982; Rauzon 1985; Doom \& Messersmith 1990; Cooper et al. 1995; Bester et al. 2000; Veitch 2001; Mitchell et al. 2002; Wood et al. 2002). Although the removal of introduced mammals, such as feral cats, from islands is a powerful conservation tool, many of these conservation successes remain unpublished or are found only in internal reports and are thus relatively inaccessible. This lack of readily available information likely inhibits progress in eradication techniques and more generally contributes to the low level of importance placed on eradication of invasive species in many conservation circles (Simberloff 2001).

We reviewed feral cat eradication campaigns on islands with the primary intent of assessing the approaches, successes, and challenges of these conservation actions to help facilitate future island conservation programs. We reviewed documented impacts of feral cat populations on island ecosystems and the recovery of native populations after cat removal. We then analyzed key aspects of these eradication campaigns to identify future directions and challenges of cat eradication. We compiled data from published and gray literature and personally communicated with over 60 researchers and conservation practitioners, covering most of the world's insular regions.

\section{Effects of Feral Cats on Insular Systems}

Cats are extremely adaptable (Coman \& Brunner 1972; Van Aarde 1986; Konecny 1987) and are found on most major island groups worldwide, including many islands inhospitable (e.g., arid, with no water) and uninhabited (Tabor 1983; Atkinson 1989). Many cat introductions were made to control rodent or rabbit populations (Flux 1993; Lever 1994). The majority of introductions took place in the nineteenth and early twentieth centuries or before; however, introductions have occurred more recently (e.g., Asunción, Coronado Norte, San Roque and Socorro islands, Baja California, Mexico). Due to the naïveté of island organisms to predation, the consequent lack of antipredator behavioral, morphological, and lifehistory responses (Stone et al. 1994), and the catholic diet of cats (Fitzgerald 1988), the impact of cat predation on island fauna has been devastating.

The cat is an opportunistic predator. On islands its diet includes a variety of mammals, reptiles, birds, and insects (Kirkpatrick \& Rauzon 1986; Konecny 1987; Fitzgerald 1988; Nogales et al. 1988; Fitzgerald \& Turner 2000). Often, primary prey is determined by relative abundance (Van Aarde 1980; Veitch 1985). Predation by cats has been directly responsible for numerous island extinctions of mammals (Mellink 1992; Tershy et al. 2002), reptiles (Iverson 1978; Mitchell et al. 2002), and birds (Jehl \& Parks 1983; Lever 1994; Dowding \& Murphy 2001; Veitch 2001).

Insular rodents have been the mammal taxon most vulnerable to cat predation. Hutias (Geocapromys spp.), an endemic group of rodents found on islands throughout the Caribbean, have been hard hit by cats and other introduced predators. A number of species are near extinction or already thought to be extinct (Fitzgerald 1988; Berovides \& Comas 1991; Nowak 1999). Endemic rodents (Nesoryzomys spp. and Oryzomys spp.) from the Galapagos Islands have also suffered dramatic declines and 
extinctions from predation by non-native rats and cats. Only four species remain, three of which are found only on islands free of introduced predators (Patton \& Hafner 1983; Dowler et al. 2000). In northwestern Mexico, cats have caused a wave of rodent extinctions on the islands of Baja California, with over 10 taxa extinct or nearly extinct (Mellink 1992; Álvarez \& Cortés 1996; Álvarez \& Ortega 2002; Mellink et al. 2002).

Cat predation on island reptiles at tropical and subtropical latitudes appears cosmopolitan (Laurie 1983; Konecny 1987; Fitzgerald 1988; Nogales et al. 1990; Arnaud et al. 1993; Nogales \& Medina 1996; Rando \& López 2001). Cats, along with other introduced predators such as mongooses (Herpestes javanicus) and rats (Rattus spp.), have played a significant role in driving recent distributions and abundances of island reptiles. These community-level processes have resulted in novel biogeographic patterns (Case \& Bolger 1991). For example, the tuatara (Spbenodon punctatus) and $40 \%$ of New Zealand lizards are now largely confined to offshore islands free of introduced predators (Daugherty et al. 1994; Towns \& Daugherty 1994). Other examples of local reptile extinctions due to cat predation are iguanas (Brachylophus spp.) and skinks (Emoia spp.) in the Fiji Islands (Gibbons 1984) and iguanas (Cyclura spp.) on islands in the Caribbean (Iverson 1978; Alberts 2000; Mitchell et al. 2002). Other reptiles, such as the endemic giant lizard (G. gomerana) from La Gomera Island (Canary Islands, Spain), are on the verge of extinction, with cat predation suspected as the major cause (Valido et al. 2000; Nogales et al. 2001).

Feral cats are responsible for the extinction of at least 33 bird species ( Lever 1994). Insular endemic landbirds are most frequently driven to extinction. The Stephen Island Wren (Traversia lyalli; New Zealand) is a noteworthy example because the last population of this species was driven to extinction by one individual cat in 1894 (Fuller 2000). Such examples lend support to the idea that only a few predators can have substantial impacts on prey demography and community-level processes (Estes et al. 1998; Roemer et al. 2001; Roemer et al. 2002). A more recent case of wild extinction occurred in Socorro Island (Mexico), where an endemic species of dove (Zenaida graysoni) disappeared in the wild and the population of an endemic passerine (Mimodes graysoni) was reduced nearly to extinction after cats were introduced by a military garrison in the late 1950s (Jehl \& Parks 1983; Martínez \& Curry 1996).

Seabirds are less frequently driven to extinction because they usually breed on more than one island; however, there have been spectacular extirpations and even extinctions caused by cats (Stonehouse 1962; Moors \& Atkinson 1984; Fitzgerald \& Veitch 1985; Veitch 1985; Fitzgerald 1988). An often-quoted example of a global seabird extinction is that of the Guadalupe Storm Petrel (Oceanodroma macrodactyla), which was restricted to
Guadalupe Island, Mexico (Jehl 1972). Van Aarde (1980) estimated that on Marion Island (sub-Antarctic island, South Africa) cats preyed on about 455,119 seabirds per year, which constitutes an annual kill rate of more than 200 individuals per cat. Pascal (1980) estimated that on Kerguelen (sub-Antarctic island, France), cats killed approximately 1.2 million seabirds each year during the 1970s. Seabirds are also severely preyed upon by cats on Ascension Island, where the Sooty Tern (Sterna fuscata) colony has been reduced from possibly more than one million pairs in the 1940s to the current estimation of about 150,000 breeding pairs (Ashmole et al. 1994).

Published studies on the recovery of populations from cat eradication are less common than impact studies; thus, most case studies remain anecdotal or in unpublished reports. Nonetheless, the benefits to biodiversity conservation are clear and significant. On Natividad Island (Mexico), for example, Keitt et al. (2002) showed that a relatively small population of cats could have driven the population of approximately 75,000 Black-vented Shearwaters (Puffinus opistbomela) to local extinction in 1050 years. When cats were present, more than 1000 shearwaters were found dead on the colony every month (Keitt et al. 2002). After cats were eradicated (Wood et al. 2002), fewer than 100 shearwaters were found dead on the colony each month (Keitt \& Tershy 2003). On Coronados Islands (Mexico), Cassin's Auklets (Ptychorampbus aleuticus) were driven to local extinction by cat predation (Jehl 1977) but recolonized the island within 4 years after cats were eradicated (Wolf 2002). On Marion Island, cat depredation caused the extinction of the Common Diving Petrel (Pelecanoides urinatrix) and severely affected some species of hole-nesting petrels (Procellariidae). Following cat eradication, hole-nesting petrels showed signs of recovery (Cooper et al. 1995), and Common Diving Petrels are again breeding on Marion Island (Hänel \& Chown 1998).

\section{Eradication on Islands}

Feral cat eradication has been carried out on at least 48 islands (Appendix 1). By geographic region, Baja California (Mexico) has had the most successful cat removals, followed by islands of New Zealand, Australia, the South Pacific, Seychelles, sub-Antarctic, Macaronesia (Atlantic Ocean), Mauritius, and the Caribbean (Fig. 1). Island areas range from $0.13 \mathrm{~km}^{2}$ (San Jerónimo, Baja California, Mexico) to $290 \mathrm{~km}^{2}$ (Marion Island, sub-Antarctic). However, the majority of islands $(75 \%, n=36)$ where eradication has been successful are $\leq 5 \mathrm{~km}^{2}$, and only 10 (21\%) are $\geq 10 \mathrm{~km}^{2}$ (Appendix 1).

The first successful campaign took place on Stephens Island, New Zealand, in 1925 (Baldwin 1981). Between 1925 and 1980, cats were removed from nine islands; 


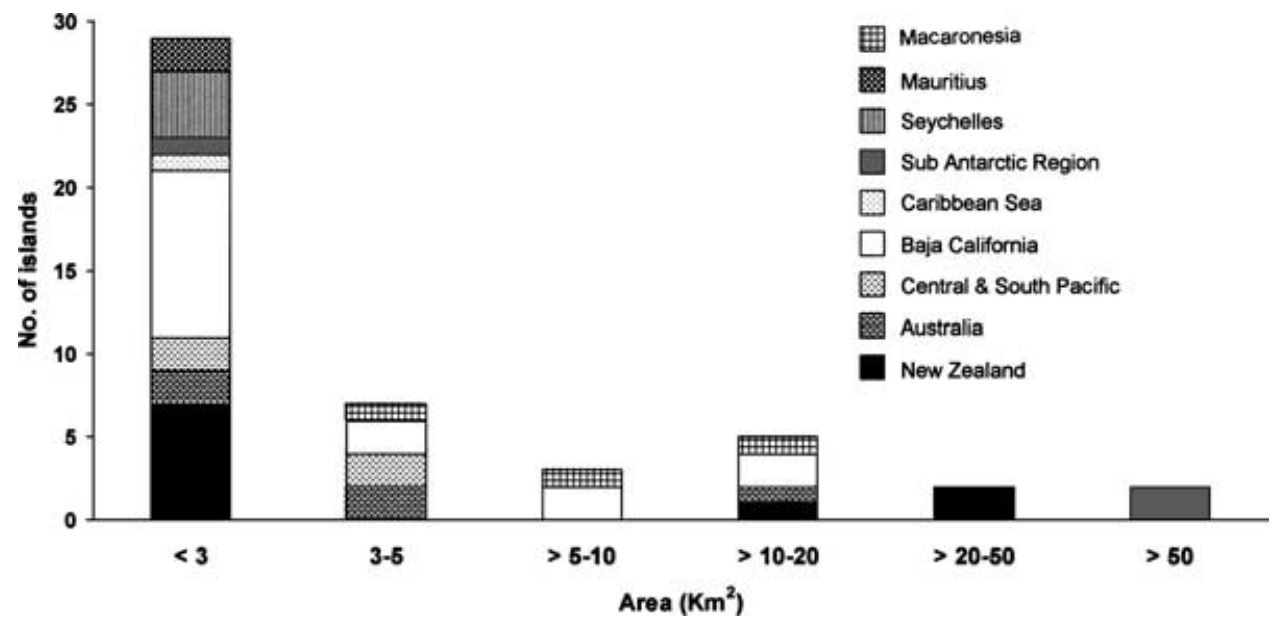

Figure 1. Location and size of the islands where feral cat (Felis catus) eradication campaigns have been successfully carried out. most are offshore islands of New Zealand (Veitch 1995). In the last 20 years there have been great successes with removal of island cats: cat populations were removed from 37 islands, 28 of them in the last decade, especially around Baja California.

On 27 islands for which cat densities have been reported, densities varied from 0.15 individuals $/ \mathrm{km}^{2}$ (Partida Sur, Mexico) to 243 individuals $/ \mathrm{km}^{2}$ (Cousine, Seychelles). However, a high number of islands ( $n=22 ; 81 \%$ ) had densities lower than 79.2 individuals $/ \mathrm{km}^{2}$.

The main methods used in eradication campaigns have been (1) trapping, (2) hunting (with dogs, rifles, and guns), (3) poisoning (in fish baits), and (4) disease introduction (mainly virus). The use of baits in traps has been combined on at least on six islands with attractive substances (urine, droppings, or gonad extracts) to improve capture results. Secondary poisoning of feral cats that consumed introduced Rattus spp. that had eaten anticoagulants, such as brodifacoum, has played a role in four insular eradication campaigns (Tuhua, Pitcairn, Curieuse, and Flat islands).

Most eradication programs used traps-commonly gin traps (Conibear and Oneida Victor, Lititz, Pennsylvania) and less frequently cage traps (Tomahawk, Tomahawk, Wisconsin-and/or hunting ( $n=39 ; 91 \%$ of the 43 islands for which information is available; Fig. 2). Hunters have used .22 and .222-caliber rifles and 12-gauge shotguns. Hunting with dogs has been carried out during the day, and at night with the aide of adjustable headlamps. More details on the methods of cat-eradication campaigns on islands have been provided by Veitch $(1985,2001)$ and Wood et al. (2002).

After hunting and trapping, the most frequently used techniques were direct poisoning ( $n=14 ; 33 \%$ of the islands), secondary poisoning ( $n=4 ; 10 \%)$, and disease introduction (5\%). To our knowledge, in most cases the only poison used has been 1080 (sodium monofluoroacetate), which has been applied on three islands in Australia, two each in the Seychelles, New Zealand, and sub-Antarctic, and one each in the central Pacific Ocean, Caribbean, and Baja California (Appendix 1). The disease agent was feline panleucopaenia virus, which was used on the islands of Jarvis and Marion (Rauzon 1985; Bester et al. 2000). Recent theoretical models based on virus-vectored immunocontraception may hold promise for future eradication campaigns (Courchamp \& Cornell 2000).

In the majority of eradication plans, several simultaneous techniques were used (e.g., Fitzgerald \& Veitch 1985; Rauzon 1985; Veitch 1985; Bester et al. 2000; Twyford et al. 2000; Wood et al. 2002). It is difficult to evaluate the relative effectiveness of these techniques because they were used by different individuals in different habitats. However, toxins and biological controls tended to be most effective at the beginning of an eradication operation, whereas hunting and especially trapping appeared to be the only effective techniques to eradicate the few remaining cats.

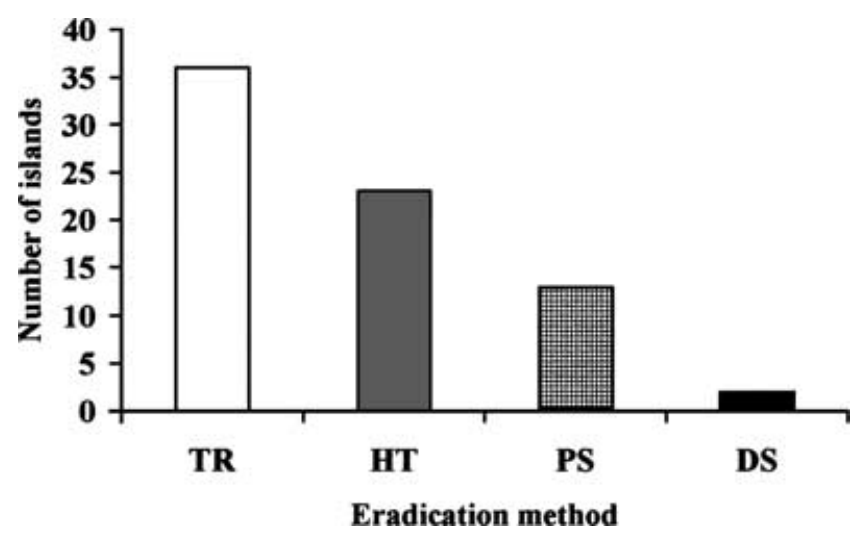

Figure 2. Use of feral cat eradication metbods employed on 44 islands: TR, traps; HT, bunting; PS, poison; and DS, disease. 


\section{Conclusions and Recommendations}

We identified 48 feral cat eradications on islands, most of which were on islands $<5 \mathrm{~km}^{2}$ in size, although a few took place on islands of $>15 \mathrm{~km}^{2}$. Considering the number of island species whose extinctions have been caused by feral cats, it is remarkable that there have been so few documented feral cat eradications. Based on the results of our review, we make the following suggestions. (1) Because of the well-documented extinctions and near extinctions of native island animals caused by feral cats, land managers should routinely eradicate feral cats from islands of $<5 \mathrm{~km}^{2}$. These eradications are particularly beneficial to seabirds, which can form extremely dense nesting colonies on these small islands. (2) With extensive planning and a greater investment of time and effort, land managers should attempt to eradicate feral cats from medium-sized islands (around 10-30 $\mathrm{km}^{2}$ ). These programs on medium-sized islands need to be well documented and supported by applied research on cat home ranges, movement patterns, and bait acceptance so that existing techniques can be refined. (3) New techniques should be developed to eradicate cats from larger islands of $>50 \mathrm{~km}^{2}$, where biodiversity and endemism levels are highest.

An example of a successful cat eradication took place on the uninhabited, large island of Marion. It took about 15 years of intense effort to eradicate the cats, combining several methods such as trapping, hunting, poisoning, and disease introduction (Bloomer \& Bester 1992; Bester et al. 2000). The use of disease agents or targeted poisoning campaigns hold promise for an initial population reduction in eradication programs on large islands- such an approach may save effort, time, and money. However, such approaches should minimize nontarget effects (see cautions given by the World Conservation Union [2000]).

Large islands are often inhabited by humans; therefore, eradication programs become more complicated by island area and because the cat has been linked to humans since historical times. Cat eradication is currently being carried out on Ascencion Island (area of $97 \mathrm{~km}^{2}$ and a human population of around 1000), one of the most important breeding places for seabirds in the tropical Atlantic (Ashmole \& Ashmole 2000).

With every eradication program on islands, the prevention of reintroduction is as important as eradication itself. Therefore, effective quarantine plans, including policies prohibiting the presence of potentially invasive pets, should be a major component of conservation plans in insular environments (especially on smaller islands). Furthermore, environmental education programs in conjunction with the eradication program are often a requisite for conservation success (e.g., Donlan \& Keitt 1999). Despite the lack of attention that non-native species eradications from islands have received from the overall conservation community, these eradication programs have been successful in stopping extinctions and in preserving biodiversity as well as ecological and evolutionary processes (Donlan et al. 2003). The recent successes on larger islands are encouraging for future island conservation.

\section{Acknowledgments}

This review would not have been possible without the collaboration of many researchers who shared all sorts of information with us, sometimes unpublished. We are especially indebted to D. Merton and B. Bell (New Zealand); A. Burbidge, P. Copley, and G. Copson (Australia); P. Oliveira (Madeira, Portugal); M. Bester, and M. Cohen (South Africa); F. Courchamp, M. Pascal, and J.-L. Chapuis (France); K. Campbell and F. Cruz (Galápagos, Ecuador); S. Roy (Mauritius); M. Rauzon, D. Goltz, E. Campbell, and D. Forsell (Hawaii, U.S.A.); N. Mitchell, M. Naughton, and R. Clapp (U.S.A.); and J. Á. Sánchez, M. Á. Hermosillo, and G. Arnaud (México). J. Berger, E. Main, D. Wenny, and two anonymous referees offered valuable comments to improve the manuscript. Basic research for this paper was conducted as part of a natural resource restoration project supported by the LIFE project (99 NAT/E/006392) of the European Union and the Cabildo Insular de Lanzarote (Canary Islands, Spain).

\section{Literature Cited}

Alberts, A. 2000. West Indian iguanas: status survey and conservation action plan. World Conservation Union, Cambridge, United Kingdom.

Algar, D. A., A. A. Burbidge, and G. J. Angus. 2002. Cat eradication on Hermite Island, Montebello Islands, Western Australia. Pages 1418 in C. R. Veitch and M. N. Clout, editors. Turning the tide: the eradication of invasive species. World Conservation Union, Gland, Switzerland

Álvarez, S. T., and P. Cortés. 1996. Anthropogenic extinction of the endemic deer mouse, Peromyscus maniculatus cineritius, on San Roque Island, Baja California Sur, Mexico. Southwestern Naturalist 41:459-461.

Álvarez, S. T., and A. Ortega. 2002. Current status of rodents on islands in the Gulf of California. Biological Conservation 109:157-163.

Ardura, E., and P. Calabuig. 1993. Depredación de pequeños procelariformes y control de gatos asilvestrados en el islote de Lobos. Unidad de fauna. Viceconsejería de Medio Ambiente. Consejería de Política Territorial. Gobierno de Canarias, Las Palmas de Gran Canaria, Spain.

Arnaud, G., A. Rodríguez-Moreno, A. Ortega, and S. Álvarez. 1993. Predation cats on the unique endemic lizard of Socorro Island (Urosaurus auriculatus), Revillagigedo, Mexico. Ohio Journal of Science 93:101-104.

Arnaud, G., A. Rodríguez-Moreno, and M. Camacho. 2000. Programa exitoso de erradicación de gatos en Isla Coronados. Baja California Sur Insulario 11 y 12:21-24.

Ashmole, P., and M. Ashmole. 2000. St. Helena and Ascencion Island: a natural history. A. Nelson, Oswestry, United Kingdom.

Ashmole, N. P., M. J. Ashmole, and K. E. L. Simmons. 1994. Seabird conservation and feral cats on Ascension Island, South Atlantic. Pages 
94-121 in D. N. Nettleship, J. Burger and M. Gochfeld, editors. Seabirds on islands. Conservation series 1. BirdLife International, Cambridge, United Kingdom.

Atkinson, I. 1989. Introduced animals and extinctions. Pages 54-75 in D. Western and M. C. Pearl, editors. Conservation for the twenty-first century. Oxford University Press, New York.

Atkinson, I. A. E. 2001. Introduced mammals and models for restoration. Biological Conservation 99:81-96.

Baldwin, O. 1981. New Zealand's French Pass and d'Urville Island. Book 2. Sea business. Fields Publishing, Plimmerton, New Zealand.

Bell, B. D., and E. Bell. 1997. Habitat restoration, Pitcairn Island, South Pacific: eradication of rats and feral cats. April to December, 1997: report. Foreign and Commonwealth Office, United Kingdom, and Pitcairn Island Administration, New Zealand.

Bell, P., and K. Lomax. 1998. Habitat restoration: Flat Island, Mauritius: eradication of rats, mice and feral cats. September to November: 1998 report. National Parks and Conservation Service, Mauritius.

Berovides, V., and A. Comas. 1991. The critical condition of hutias in Cuba. Oryx 25:206-208.

Bester, M. N., J. P. Bloomer, P. A. Bartlett, D. D. Muller, M. Van Rooyen, and H. Büchner. 2000. Final eradication of feral cats from subAntarctic Marion Island, southern Indian Ocean. South African Journal of Wildlife Research 30:53-57.

Bloomer, J. P., and M. N. Bester. 1992. Control of feral cats on subAntarctic Marion Island, Indian Ocean. Biological Conservation 60:211-219.

Case, T. J., and D. T. Bolger. 1991. The role of introduced species in shaping the distribution and abundance of island reptiles. Evolutionary Ecology 5:272-290.

Chapuis, J. L., and Y. Frenot. 1996. Restauration d'îles subantarctiques françaises: programmes en cours sur l'île Amsterdam et dans l'archipel de Kerguelen. Pages 38-43 in Rapport d'activité 1995. Institut Français Pour la Recherche et la Technologie Polaires, Brest.

Clapperton, B. K., R. J. Pierce, and C. T. Eason. 1992. Experimental eradication of feral cats (Felis catus) from Matakohe (Limestone) Island, Whangarei Harbour. Science and research internal report 54. Department of Conservation, Wellington, Australia.

Coman, B. J., and H. Brunner. 1972. Foods habits of the feral house cat in Victoria. Journal of Wildlife Management 36:848-853.

Cooper, J., A. V. N. Marais, J. P. Bloomer, and M. N. Bester. 1995. A success story: breeding of burrowing petrels (Procellariidae) before and after the eradication of feral cats Felis catus at subantarctic Marion Island. Marine Ornithology 23:33-37.

Copson, G., and J. Whinam. 2001. Review of ecological restoration program on sub-Antarctic Maquarie Islands: pest management progress and future directions. Ecological Management and Restoration 2:129-138.

Courchamp, F., and S. J. Cornell. 2000. Virus-vectored immunocontraception to control feral cats on islands: a mathematical model. Journal of Applied Ecology 37:903-923.

Cruz, J. B., and F. Cruz. 1987. Conservation of the Dark-Rumped Petrel Pterodroma-Phaeopygia in the Galapagos Islands, Ecuador. Biological Conservation 42:303-312.

Daugherty, C. H., G. B. Patterson, and R. A. Hitchmough. 1994. Taxonomic and conservation review of the New Zealand herpetofauna. New Zealand Journal of Zoology 21:317-323.

Donlan, C. J., and B. S. Keitt. 1999. Using research and education to prevent extinction. California Coast and Ocean 15:20-23.

Donlan, C. J., B. R. Tershy, B. S. Keitt, B. Wood, J. A. Sánchez, A. Weinstein, D. A. Croll, and J. L. Aguilar. 2000. Island conservation action in northwest Mexico. Pages 330-338 in D. H. Browne, H. Chaney, and $\mathrm{K}$. Mitchell, editors. Proceedings of the fifth California Islands symposium. Santa Barbara Museum of Natural History, Santa Barbara, California.

Donlan, C. J., B. R. Tershy, K. J. Campbell, and F. B. Cruz. 2003. Research for requiems: the need for more collaborative action. Conservation Biology 17:1850-1851.
Doom, S., and J. Messersmith. 1990. Feral cat eradication on a barrier reef island. Australia. Atoll Research Bulletin 338:1-4.

Dowding, J. E., and E. C. Murphy. 2001. The impact of predation by introduced mammals on endemic shorebirds in New Zealand: a conservation perspective. Biological Conservation 99:47-64.

Dowler, R. C., D. S. Carroll, and C. W. Edwards. 2000. Rediscovery of rodents (Genus Nesoryzomys) considered extinct in the Galapagos Islands. Oryx 34:109-117.

Estes, J. A., M. T. Tinker, T. M. Williams, and D. F. Doak. 1998. Killer whale predation on sea otters linking oceanic and near shore ecosystems. Science 282:473-476.

Fitzgerald, B. M. 1988. Diet of domestic cats and their impact on prey populations. Pages 123-147 in D. C. Turner and P. Bateson, editors. The domestic cat: the biology of its behaviour. Cambridge University Press, Cambridge, United Kingdom.

Fitzgerald, B. M., and C. R. Veitch. 1985. The cats of Herekopare Island, New Zealand: their history, ecology and effects on birdlife. New Zealand Journal of Zoology 12:319-330.

Fitzgerald, B. M., and B. M. Turner. 2000. Hunting behaviour of domestic cats and their impact on prey populations. Pages 151-175 in D. C. Turner and P. Bateson, editors. The domestic cat: the biology of its behaviour. Cambridge University Press, Cambridge, United Kingdom.

Flux, J. E. C. 1993. Relative effect of cats, myxomatoxis, traditional control, or competitors in removing rabbits from islands. New Zealand Journal of Zoology 20:13-18.

Forsell, D. J. 1982. Recolonization of Baker Island by seabirds. Bulletin of the Pacific Seabirds Group 9:75-76.

Fuller, E. 2000. Extinct birds. Oxford University Press, Oxford, United Kingdom.

Gibbons, J. 1984. Iguanas of the South Pacific. Oryx 18:82-91.

Groombridge, B., and M. D. Jenkins. 2000. Global biodiversity: Earth's living resources in the 21st century. United Nations Environmental Programme, World Conservation Monitoring Centre, and World Conservation Press, Cambridge, United Kingdom.

Hänel, C., and S. Chown. 1998. An introductory guide to the Marion and Prince Edward Island special nature reserves. Department of Environmental Affairs and Tourism, Pretoria, South Africa.

Iverson, J. B. 1978. The impact of feral cats and dogs on populations of the West Indian rock iguana, Cyclura carinata. Biological Conservation 14:63-73.

Jehl, J. R. 1972. On the cold trail of an extinct petrel. Pacific Discovery 25:24-29.

Jehl, J. R. 1977. An annotated list of the birds of the Los Coronados Islands, Baja California, and adjacent waters. Western Birds 8:91101.

Jehl, J. R., and K. C. Parks. 1983. 'Replacements' of landbird species on Socorro Island, Mexico. Auk 100:551-559.

Keitt, B. S., and B. R. Tershy. 2003. Cat eradication significantly reduces shearwaters mortality. Animal Conservation 6:307-308.

Keitt, B. S., C. Wilcox, B. R. Tershy, D. A. Croll, and C. J. Donlan. 2002. The effect of feral cats on the population viability of Black-vented Shearwaters (Puffinus opisthomelas) on Natividad Island, Mexico. Animal Conservation 5:217-223.

Kirkpatrick, R. D., and M. J. Rauzon. 1986. Foods of feral cats Felis catus on Jarvis and Howland Islands, central Pacific Ocean. Biotropica 18:72-75.

Konecny, M. J. 1987. Food habits and energetics of feral house cats in the Galapagos Islands. Oikos 50:24-32.

Laboudallon, V. 1987. Cat eradication on Cousine Island, Seychelles. International Council for Bird Preservation, Cambridge, United Kingdom.

Laurie, A. 1983. Marine iguanas in Galapagos. Oryx 17:18-25.

Lever, C. 1994. Naturalized animals. T \& A.D. Poyser Natural History, London.

Lowe, S., M. Browne, S. Boudjelas, and M. De Poorter. 2001. 100 of the world's worst invasive alien species: a selection from the global 
invasive species database. Species Survival Commission, World Conservation Union, Auckland, New Zealand.

Martín, A., et al. 2002a. Restauración de los Islotes y del Risco de Famara (Lanzarote). Departamento de Biología Animal (Zoología), Universidad de La Laguna, Tenerife, Islas Canarias, Spain.

Martín, A., J. A. Lorenzo, B. Rodríguez, and M. Nogales. 2002b. Erradicación de gatos asilvestrados en el islote de Lobos. Departamento de Biología Animal (Zoología), Universidad de La Laguna, Tenerife, Islas Canarias, Spain.

Martínez, J. E., and R. L. Curry. 1996. The conservation status of the Socorro Mockingbird Mimodes graysoni in 1993-1994. Bird Conservation International 6:271-283.

McNeely, J. A., H. A. Mooney, L. E. Neville, P. Shei, and J. K. Waage, editors. 2001. A global strategy on invasive alien species. World Conservation Union, Gland, Switzerland.

Mellink, E. 1992. The status of Neotoma anthonyi (Rodentia, Muridae, Cricetinae) of Todos Santos Islands, Baja California, Mexico. Bulletin of the Southern California Academy of Sciences 91:137-140.

Mellink, E., G. Ceballos, and J. Luevano. 2002. Population demise and extinction threat of the Angel de la Guarda deer mouse (Peromyscus guardia). Biological Conservation 108:107-111.

Merton, D. 1970. The rehabilitation of Cuvier Island: a review. Wildlife 1970:5-8.

Merton, D., G. Climo, V. Laboudallon, S. Robert, and C. Mander. 2002. Alien mammal eradication and quarantine on inhabited islands in the Seychelles. Pages 182-198 in C. R.Veitch and M. N. Clout, editors. Turning the tide: the eradication of invasive species. World Conservation Union, Gland, Switzerland.

Mitchell, N., R. Haeffner, V. Veer, M. Fulford-Gardner, W. Clerveaux, C. R. Veitch, and G. Mitchell. 2002. Cat eradication and the restoration of endangered iguanas (Cyclura carinata) on Long Cay, Caicos Bank, Turks and Caicos Islands, British West Indies. Pages 206-212 in C. R. Veitch and M. N. Clout, editors. Turning the tide: the eradication of invasive species. World Conservation Union, Gland, Switzerland.

Moors, P. J. 1985. Conservation of island birds: case studies for the management of threatened island birds. International Council for Bird Preservation, Cambridge, United Kingdom.

Moors, P. J., and A. E. Atkinson. 1984. Predation on seabirds by introduced animals, and factors affecting its severity. Pages 667-690 in Technical publication 2. International Council for Bird Preservation, Cambridge, United Kingdom.

Nogales, M., and F. M. Medina. 1996. A review of the diet of feral domestic cats (Felis sylvestris f. Catus) on the Canary Islands, with new data from the laurel forest of La Gomera. Zeischrift für Säugetierkunde 61:1-6.

Nogales, M., A. Martín, G. Delgado, and K. Emmerson. 1988. Food spectrum of the feral cat (Felis catus L., 1758) in the juniper woodland on El Hierro (Canary Islands). Bonner Zoologische Beiträge 39:1-6.

Nogales, M., M. Abdola, C. Alonso, and V. Quilis. 1990. Premières données sur l'alimentation du chat haret (Felis catus L., 1758) du Parc National du Teide, Ténérife (Iles Canaries). Mammalia 54:189196.

Nogales, M., J. C. Rando, A. Valido, and A. Martín. 2001. Discovery of a living giant lizard, genus Gallotia (Reptilia: Lacertidae), from La Gomera, Canary Islands. Herpetologica 57:169-179.

Nowak, R. M. 1999. Walker's mammals of the world. Johns Hopkins University Press, Baltimore, Maryland.

Parr, S. J., M. J. Hill, J. Nevill, D. V. Merton, and J. Shah. 2000. Alien species case study: eradication of introduced mammals in Seychelles in 2000. World Conservation Union, Gland, Switzerland.

Pascal, M. 1980. Structure et dynamique de chats harets de l'archipel des Kerguelen. Mammalia 44:161-182.

Patton, J. L., and M. S. Hafner. 1983. Biosystematics of the native rodents of the Galapagos archipelago, Ecuador. Pages 539-568 in R. I. Bowman, M. Berson, and A. E. Leviton, editors. Patterns of evolution in Galapagos organisms. American Association for the Advancement of Science, Pacific Division, San Francisco.
Pedler, L., and P. B. Copley. 1993. Re-introduction of stick-nest rats to Reevesby Island, South Australia. Biological Conservation Branch, Department of Environment and Land Management, Canberra, Australia.

Randi, E., and B. Ragni. 1991. Genetic variability and biochemical systematics of domestic and wild cat populations (Felis silvestris: Felidae). Journal of Mammalogy 72:79-88.

Rando, J. C., and M. López. 2001. Actuaciones para la conservación del Lagarto Canario Moteado (Gallotia intermedia). Consejería de Política Territorial y Medio Ambiente del Gobierno de Canarias, Santa Cruz de Tenerife, Spain.

Rauzon, M. J. 1985. Feral cats on Jarvis Island: their effects and their eradication. Atoll Research Bulletin 282:1-32.

Rauzon, M. J., D. J. Forsell, and E. N. Flint. 2002. Seabird re-colonisation after cat eradication on equatorial Jarvis, Howland, and Baker Islands, USA, Central Pacific. Page 411 in C. R. Veitch, and M. N. Clout, editors. Turning the tide: the eradication of invasive species. World Conservation Union, Gland, Switzerland.

Rodríguez Luengo, J. L., and P. Calabuig. 1993. Programa de control de gatos asilvestrados en la isla de Lobos. Sección de flora y fauna, Viceconsejería de Medio Ambiente. Consejería de Política Territorial y Medio Ambiente del Gobierno de Canarias, Santa Cruz de Tenerife, Spain.

Roemer, G. W., T. J. Coonan, D. K. Garcelon, J. Bascompte, and L. Laughrin. 2001. Feral pigs facilitate hyperpredation by golden eagles and indirectly cause the decline of the island fox. Animal Conservation 4:307-318.

Roemer, G. W., C. J. Donlan, and F. Courchamp. 2002. Golden eagles, feral pigs and insular carnivores: how exotic species turn native predators into prey. Proceedings of the National Academy of Sciences of the United States of America 99:791-796.

Serpell, J. A. 2000. Domestication and history of the cat. Pages 179-192 in D. C. Turner and P. Bateson, editors. The domestic cat: the biology and its behaviour. Cambridge University Press, Cambridge, United Kingdom.

Simberloff, D. 2001. Eradication of island invasives: practical actions and results achieved. Trends in Ecology \& Evolution 16:273-274.

Stone, P. A., H. L. Snell, and H. M. Snell. 1994. Behavioral diversity as biological diversity: Introduced cats and lava lizard wariness. Conservation Biology 8:569-573.

Stonehouse, B. 1962. Ascencion Island and the British Ornithologists' Union Centenary Expedition 1957-1959. Ibis 103B:107-123.

Tabor, R. K. 1983. The wild life of the domestic cat. Arrow Books, London.

Tennyson, A. J. D., and P. R. Millener. 1994. Bird extinctions and fossil bones from Mangere Island, Chatham Islands. Notornis 41:165-178.

Tershy, B. R., C. J. Donlan, B. S. Keitt, D. A. Croll, J. A. Sánchez, B. Wood, M. A. Hermosillo, G. R. Howald, and N. Biavaschi. 2002. Island conservation in north-west Mexico: a conservation model integrating research, education and exotic mammal eradication. Pages 293-300 in C. R. Veitch and M. N. Clout, editors. Turning the tide: the eradication of invasive species. World Conservation Union, Gland, Switzerland.

Todd, L. 1977. Cats and commerce. Scientific American 237:100-107.

Towns, D. R., and C. H. Daugherty. 1994. Patterns of range contractions and extinctions in the New Zealand herpetofauna following human colonisation. New Zealand Journal of Zoology 21:325-339.

Towns, D. R., I. A. E. Atkinson, and C. H. Daugherty. 1990. Ecological restoration of New Zealand islands: papers presented at conference on ecological restoration of New Zealand islands 1989. Department of Conservation, Wellington, New Zealand.

Twyford, K. L., P. G. Humphrey, R. P. Numm, and L. Willoughby. 2000. Eradication of feral cats (Felis catus) from Gabo Island, south-east Victoria. Ecological Management \& Restoration 1:42-49.

Valido, A., J. C. Rando, M. Nogales, and A. Martín. 2000. 'Fossil' lizard found alive in the Canary Islands. Oryx 34:75-76.

Van Aarde, R. J. 1978. Reproduction and population ecology in the 
feral house cats, Felis catus, at Marion Island. Carnivore Genetics Newsletter 3:288-316.

Van Aarde, R. J. 1980. The diet and feeding behaviour of feral cats, Felis catus at Marion Island. South African Journal of Wildlife Research 10:123-128.

Van Aarde, R. J. 1986. A case study of an alien predator (Felis catus) introduced on Marion Island: selective advantages. South African Antarctic Research 16:113-114.

Van Aarde, R. J., and J. D. Skinner. 1981. The feral cat population at Marion Island: characteristics, colonization and control. Colloque sur les ecosystèmes subantarctiques. Comité Nationale Française des Recherches antarctiques 51:281-288.

Veitch, C. R. 1985. Methods of eradicating feral cats from offshore islands in New Zealand. Pages 125-141 in Technical publication 3. International Council for Bird Preservation, Cambridge, United Kingdom.

Veitch, C. R. 1995. Habitat repair: a necessary prerequisite to translocation of threatened birds. Pages 97-104 in M. Serena, editor. Reintroduction biology of Australian and New Zealand fauna. Surrey Beatty \& Sons, Chipping Norton, New South Wales, Australia.
Veitch, C. R. 2001. The eradication of feral cats (Felis catus) from Little Barrier Island, New Zealand. New Zealand Journal of Zoology 28: $1-12$.

Whittaker, R. J. 1998. Island biogeography: ecology, evolution and conservation. Oxford University Press, Oxford, United Kingdom.

Wilkinson, A. S., and late Amy. 1952. Kapiti bird sanctuary - a natural history of the island. Masterton Printing, Masterton, New Zealand.

Wolf, S. G. 2002. Relative status and conservation of island breeding seabirds in California and northwestern Mexico. M.S. thesis. University of California, Santa Cruz.

Wood, B., B. R. Tershy, M. A. Hermosillo, C. J. Donlan, J. A. Sánchez, B. S. Keitt, D. A. Croll, G. R. Howald, and N. Biavaschi. 2002. Removing cats from islands in north-west Mexico. Pages 374-380 in C. R. Veitch and M. N. Clout, editors. Turning the tide: the eradication of invasive species. World Conservation Union, Gland, Switzerland.

World Conservation Union (IUCN). 2000. Guidelines for the prevention of biodiversity loss caused by alien invasive species. IUCN, Gland, Switzerland. Available from http://iucn.org/themes/ssc/pubs/policy/ invasiveseng.htm (accessed February 2000). 


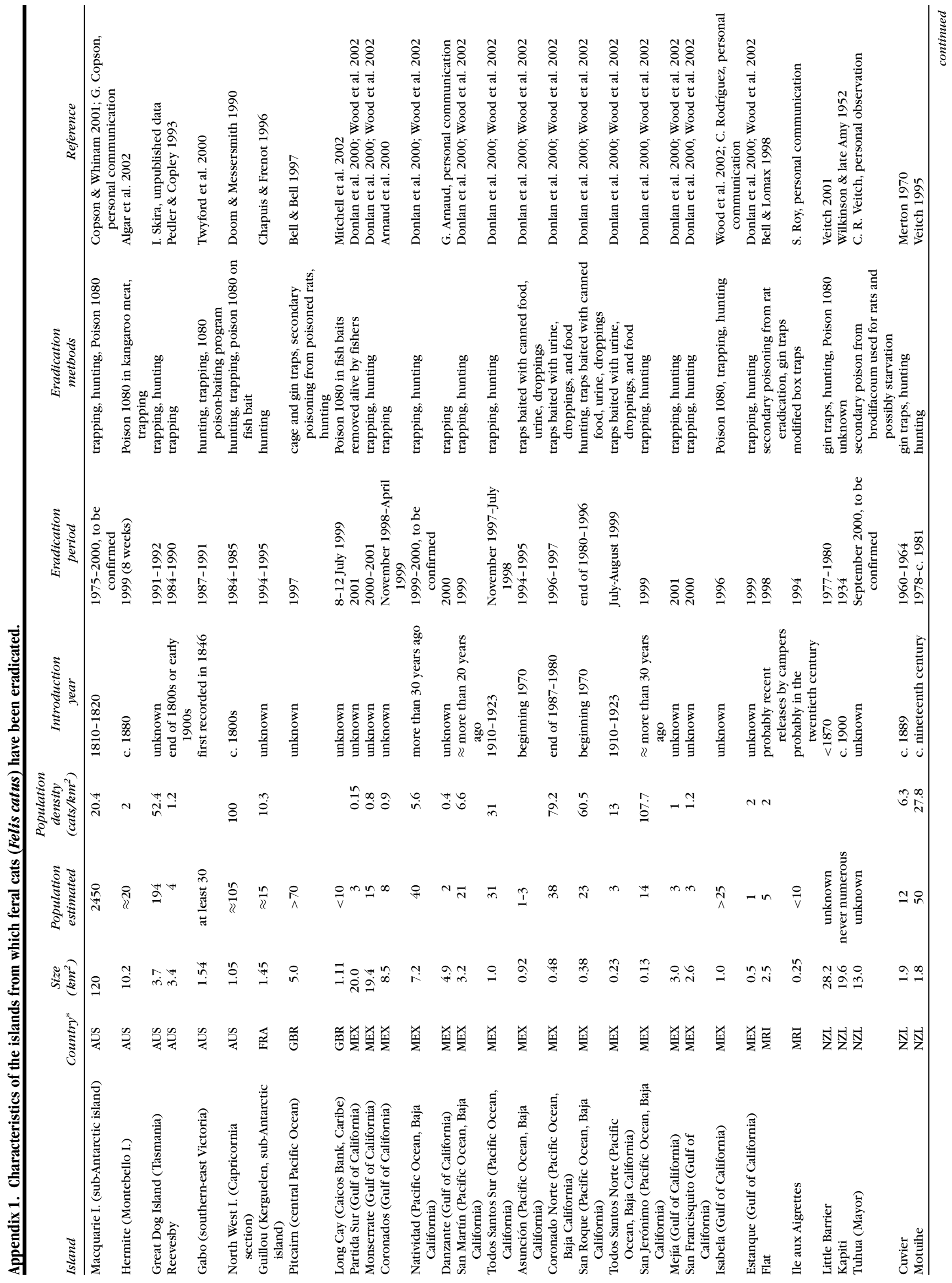




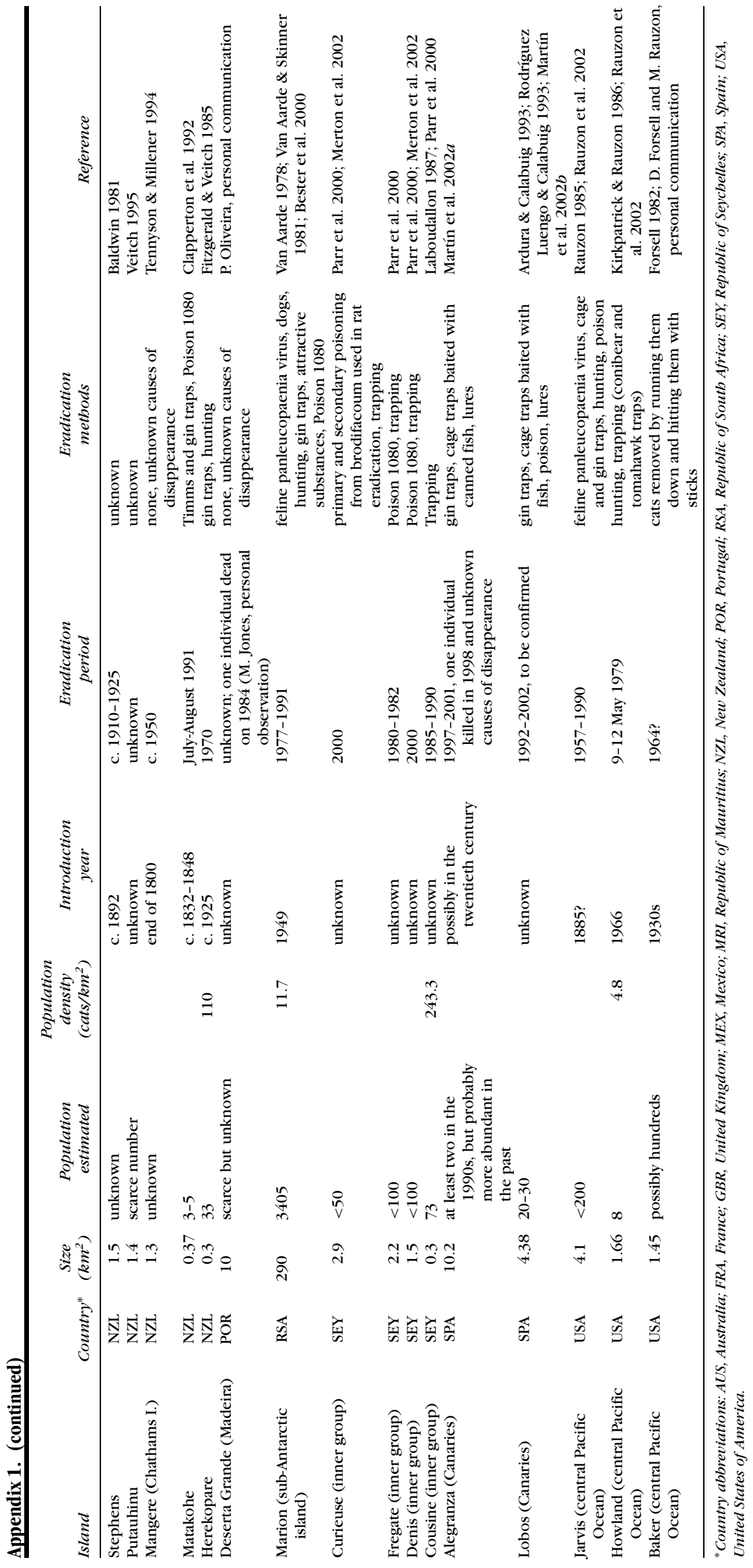

